\title{
Comparative Projections of "Life is a Fair" Model in Artistic Consciousness at the Turn of the Nineteenth-Twentieth Centuries: Realistic and Modernist Tendencies
}

\author{
Victoriia Dmytrenko ${ }^{1}$ Olena Brovko ${ }^{2}$ Nailia Khairulina, ${ }^{3, *}$
}

\author{
${ }^{1}$ Kryvyi Rih State Pedagogical University, Ukraine \\ ${ }^{2}$ Borys Grinchenko Kyiv University, Ukraine \\ ${ }^{3}$ Luhansk State University of Internal Affairs named after E. O. Didorenko, Ukraine \\ *Corresponding author.Email: nailiakhairulina@gmail.com
}

\begin{abstract}
The article comprehensively reveals how the artistic model of "life is a fair" functions in realistic and modernist Ukrainian and English literature. In the article under consideration, the model "life is a fair" is one variant of the world's artistic design with a system of values, specific types of characters. The works unite a standard world model, a writer's reaction to challenges for a person's transformation to the goods. The study aims to identify the artistic model of "life is a fair" in realistic and modernist Ukrainian and English literary works. The authors aim to reveal the artistic model through the characteristics of the main characters, who live by the principle that everything is sold and bought. This motto is very relevant today. The research methodology grounds on the involvement of comparative-typological, cultural-historical, mythopoetic, and semiotic methods. The integration of the semiotic approach into the methodology of literary criticism has conditioned the functioning of the actual concept of "model" in its terminology. As a result of a comparative study of precedent texts, the specifics of the transformation of the plot motive of the fair into a model of individual-authorial picture of the world in the texts of realism, early and mature modernism were revealed. The research results intend to create a basis for a comparative study of the artistic model of "life as a fair" in the literature of postmodernism and metamodernism.
\end{abstract}

Keywords: artistic model "life is a fair," semiotics, realism, modernism, comparative studies, motive.

\section{INTRODUCTION}

In modern studies, the artistic model "life is a fair" is investigated in different contexts: the fair as a performance, the fair as a place to buy goods, the fair as an ethnocultural tradition, expressed in the methodology and results of the study.

The transdisciplinary nature of the "life is a fair" model as a factor in constructing a picture of the world. The phenomenon of fairing is in the field of research attention of representatives of various areas of knowledge. Thus, folklorist Anna Nekrylova considered fair activities in the context of urban entertainment culture [1]. Culturologist Natalia Izhikova focused on the socio-economic and theatrical components of the fair tradition [2]. The dissertation of Andrey Golitsyn [3] is devoted to researching theoretical, systematic, and applied aspects of the enterprises' exhibition and fair activity as valuable tools of their marketing communication policy. Vitalina Yurchenko emphasizes that the fair's ethnocultural specifics reflect the Ukrainians' peculiarities, historical, socio-economic, spiritual development, and ethnic worldview [4].

Artistic experience of implementing the model of "life is a fair" has been represented in the literature of different countries for a long time. In Ukrainian literature, its origin took place in the ancient one. The genesis of the fair's artistic reproduction in the national tradition dates back to ancient Ukrainian literature. Tetiana Riazantseva [5] and Olha Novik [6] drew attention to the fact that the symbolization of the fair in Baroque artists' aesthetics was one of the artistic modeling parameters of the world. In the 
interlude-dialogue "Yarmarok" (1790) by Ivan Nekrashevich, the authors notice the features of folk laughter culture [7, 240].

Mykola Hohol skillfully recreated the fair as a national holiday, for which they prepare in advance, where all the best are selected, in the novels "The Sorochyn Fair" (1832) and "The Portrait" (18331834). Naturally, in literary studies, the fair's motive is considered primarily on the material of Mykola Hohol's works $[8 ; 9,10]$.

The analysis of the latest publications testifies to the urgency and expansion of the research issues of this topic. Svitlana Bybyk analyzes the concept of "fairs," designed the language of works of art by G. Kvitka-Osnovianenko, I. Nechui-Levytskyi, S. Rudanskii, O. Vishnia [11].

Svitlana Lenska explored the intertextual connections of the Ukrainian diaspora writer Olena Zvychna "Myrhorod Fair" with Mykola Hohol [12].

One of the authors tried to investigate this topic in English and Ukrainian literature in her thesis. But this paper expands the ideas and is enriched with brighter examples from world literature. Nailia Khairulina's previous publications noted that the abstract nature of the expression of the "life is a fair" model in literature has entirely factual features that should not be equated with the images of "life as a bazaar," "in life as a market," bazaar is different "[13].

The Ukrainian Explanatory Dictionary provides the following explanations of these terms:

1) Fair (from the German. Jahrmarkt, literally annual auction) - auctions that take place regularly at a particular time in a specific location, where people come to sell and buy goods, concluding trade agreements.

2) The bazaar is a place for the retail sale of food and organized particular trade-in goods during a tremendous demand for them.

3) Market - a retail sale of food and other goods; bazaar [14].

How autonomous and hermetic are these topos in the artistic individual-author interpretation and different national pieces of literature' stylistic systems?

\section{RESEARCH METHODOLOGY}

Comparative study of the fair as the author's model of the world in various national literature is highlighted by the typological method in typological comparison of the classical and modern life understanding as a fair. The experience of mythological criticism and symbolist anthropology allows identifying the levels of a mythologization of the world, society, and humans. The structuralsemiotic methodology is involved in detecting features of figurative author's models of life-fair in artistic text.

Studies of the fair's motive in Ukrainian literature are based primarily on carnival culture ideas by Mikhailo Bakhtin and studies of mythopoetics and symbolist anthropology by Olha Freidenberg. In the research, the authors involve Olha Freidenberg's associative-semantic approach to genetically similar plot motives of life as a fair. Essential in the comparative study of English and Ukrainian literature texts are the concepts of motive and artistic model. We understand the motive as the most straightforward indivisible semantic unit of plot development. Motive is a flexible category. It can transform the artistic structure of the work. The plot dynamics of the work form its semiotic model.

In this context, the most productive, in our opinion, is the definition and parameters of the artistic model, outlined by Olha Bashkyrova, who emphasizes that the basis of the artistic model is the iconic-semantic "core", closely related to the deep layers of mental consciousness of certain cultures [15]. Accordingly, the artistic model is perceived as a generalization of the artistic picture of the world represented by a literary work and has a multilevel structure/“'Its deep layers embody archaic mental ideas; genre features, architectonics, a system of characters and plot connections, narrative strategies constitute dynamic levels of existence of the artistic whole," to a greater extent correlating with the dominant style and featuresof the literary process of a specific era [16].

The principle of artistic modeling makes it possible to structure the universal motif of "life is aaa fair" to identify familiar and differences in the author's local models of the world in different national pieces of literature.

The article aims to represent typological similarities and the specifics of the artistic model of "life is a fair" in realistic and modernist works of Ukrainian and English literature of the nineteenth and twentieth centuries.

\section{RESEARCH RESULTS}

In world literature, the active embodiment of the artistic model of "life is a fair" is observed in the second half of the nineteenth century in the works of writers who directly used the image of the fair. Ben Johnson "Bartholomew Fair," W. Thackeray "Vanity 
Fair," R. Roland "La Foire Sur la Place," "JeanChristophe, I. Nechui-Levytskyi "Rokovyi Ukrainskyi Yarmarok" (Fateful Ukrainian Fair), V. Vynnychenko "Kuplia" (Purchase), "Bazaar" Leopold Ritter von Sacher-Masoch "Women's samples from Galicia” are the brightest patterns. The active use of this model is directly related to the rapid development of trade relations in society, which led to the dynamic transformation of man into a commodity. In these works, the authors see a gallery of different characters united by a common desire to sell themselves as expensive as possible at the fair of life.

A more detailed analysis of representatives of different national literature pieces' artistic practices proves that the analyzed model's artistic parameters function in the classical and modern tradition in various manifestations. Polystylistic, form-content, narrative among them constitute the specific creative search and the actual search of each era. For example, in Romain Rolland's epic novel "Jean Christophe" (1915), the semiotic model "life is a fair" acquires additional connotations and corresponding components, which become the modes of bargaining, sales, and art."

The authors observe the embodiment of different stylistic versions of the artistic-semiotic model of "life is a fair" in Panas Myrnyi's socio-psychological realistic novel "Poviia" ("Prostitute", 1883), where the main character Khrystia Prytyka is forced to sell her body because of her mother's debts.

“- Where is God taking you? (Maria)

- To the city. (Kyrylo)

- What for? At the bazaar? (Maria)

- To the bazaar. He is selling her. (Kyrylo)

- Look here, uncle, don't get cheap. Make such a reasonable price for such a young and good girl! (Maria)" [17].

Also, for the sake of the relatives' happiness, the character is compelled to marry at the expense of Olha Kobylianska's non-romantic novel "Liudyna" (A Human, 1886). In Valerian Pidmohylnyi's urban intellectual novel "Misto" (The City, 1928), the protagonist "turns himself into a commodity," sold "to the city for the sake of social status, material wealth, urban comfort" [13]. It is no coincidence that Stepan Radchenko is called "Ukraine's favorite friend." The protagonist of V. Pidmohylnyi is on a par with the hero of Guy de Maupassant's pamphlet novel "Dear Friend" and T. Dreiser's realistic novels "Sister Carey", "An American Tragedy" and others.
Researcher I. Devdiuk states: "An important issue in the research context is the question of the character's self-awareness in a city - to be oneself or not to be oneself, to be or to have" $[15,74]$.

The allegory of the fair from John Banyan's religious-didactic poem "The Pilgrim's Progress from This World to That Which Is to Come" (1678-1688) acquired new manifestations in William Thackeray's artistic interpretation in "The Vanity Fair" (18471848). English realism strongly connected with the Enlightenment literature, traditions that led artists to didacticism and moral categories. Criticizing all aspects of modern life, English writers relied on domestic and moralistic educational novel experiences. They introduced into the realistic structure of their own works symbolism and metaphor, satirical coloring.

A characteristic feature of the realistic English novel is that an essential role in it belonged to the ethical and moral factor. We mean the ethical and moral doctrine based on the Protestant ethics of English early capitalist society. The principle will be manifested in the works due to the actualization of ethical tasks, moral norms, and the tendency to interpret life phenomena in the ethical and moral system's coordinates.

English novelists exposed such diseases of society as snobbery, selfishness, vanity and created the humanistic ideals of morally healthy people capable of self-sacrifice. Based on the Enlightenment novel's traditions, modern newspapers and magazines enriched the story with journalism elements, direct controversy with existing ideas and philosophical concepts. C. Dickens, W. Thackeray, sisters Bronte, E. Gaskell introduced symbolism and metaphor into the story's realistic structure. Moreover, the elements of theater, parody, satire, expanding the artistic image's functionality and the importance of the character's independence, improved dialogue.

The master of satire W. Thackeray chose the symbolic title of his novel. He integrated it into the text of a puppeteer who tries to show all the English aristocracy's spiritual and material defects from a neutral point of view. In one of his letters to his mother, he wrote: "What I want is to make a set of people living without God in the world (only that is a cant phrase) greedy pompous mean perfectly selfsatisfied for the most part and at ease about their superior virtue." [18]. It is essential to describe the life of Becky Sharp. The comments aptly provided by the author are not at all critical or praiseworthy. The English novelist leaves the reader the right to choose what the "life-fair" model is for himself. 
In the novel by satirist $\mathrm{W}$. Thackeray, we see the "transformation" of Becky Sharp into a commodity from the very first pages. Back in the boarding house, where she was constantly humiliated and reminded that the girl is here out of kindness, Rebecca realized that you could not rely on friendships and social status in life. She needs to fight with their skills and talents, the only way to sit in society a worthy place. Trying to please Emilia Sedley's parents and brother, charming Becky is ready to go for any tricks. She later "sold" to London society, dreaming of becoming part of it. Throughout her life, Rebecca Sharp lives by the principle: there are no virtues, there are only circumstances. Finally becoming a commodity at the vanity fair, the woman lost the most precious thing: a sincerely loving husband, a son, the affection of a devoted friend, and her conscience.

Typologically close to Rebecca Sharp is the image of Anela Angarovich from Ivan Franko's novel "For the hearth." Unlike W. Thackeray, I. Franko depicts the beautiful mistress and good mother Anelia Angarovich before telling her moral decline's shameful story.

The common problems give grounds to compare two works of utterly different volume in ideologicalaesthetic and factual (612 and 154 pages), which contain the same philosophical model of "life is a fair."

An indisputable fact of Ivan Franko's interest in W. Thackeray's work is his library of copies of "Mono-descriptive essays and travels in London" and W. Thackeray's novel "Newcomas" in Russian translation by V. Butuzov, published in the supplement to Sovremennik in 1856.

The social conditionality of the characters created by the authors can be traced quite clearly and convincingly. For example, the heroines Becky Sharp and Anelya Angarovich came from low-income families, so the desire to get rich has always been dominant in women's lives. Emilia Sedley, growing in wealth and harmony of the soul, has never had such an all-encompassing task.

The materials included in the 50-volume academic edition of I. Franko's works also testify that the Ukrainian writer always kept in view the pieces of his English colleague (articles "Internationalism and Nationalism in Modern Literature" (1898); "The Dark Kingdom" (1881)). W. Thackeray's name was repeatedly mentioned in I. Franko's letters to M. Drahomanov. Thus, in one of his letters, I. Franko wrote that it would be good to find several seminarians who would translate into Ukrainian V. Thackeray's novel "The Merchant of Emptiness" (this is how
I. Franko scolded the Polish title of the story "For The Home Sake" (Dlia Domashnoho Ohnyshcha) "Targowisko proinosci"). This fact proves that I. Franco considered the work one of the most important British writer achievements and intended to publish his translation in the "Small Library," which established to promote and disseminate the best works of foreign literature among the people Galicia.

All these facts and the conclusions of authoritative French scholars (M. Tkachuk [19], etc.), comparativists (D. Zatonsky [20], D. Nalyvayko [21]) give grounds to claim that the Ukrainian writer was familiar with the primary texts of W. Thackeray. I. Franko had the "reach" of his artistic traditions and this, above all, creates sufficient conditions for a comparative study of their work.

The goal of $\mathrm{W}$. Thackeray as a realist writer was to build a natural structure of the novel, which would be similar to the natural course of human life. He sought not to portray a positive hero but skillfully intertwined individual human destinies. The most common artistic tool he uses is irony. It is worth noting that the artist gradually and "carefully" revealed the negative features of contemporary bourgeois society. Thus, the source of the famous novel "Fair of Vanity" (1848) was "The Book of Snobs, written by one of them" (1846-1847). From this work that W. Thackeray begins to vividly demonstrate to the reader the magical power of money over people, and they can buy and sell everything in the world.

Franko, in contrast to W. Thackeray, the perception of the world with the priority of the monetary aspect caught in reality. Considering the actual resonant events in the Lviv region and the dire need for money, the artist decides to create a realistic novel, "For the hearth" (1892). Using the thesis of I. Denisyuk, artistic experiments in the psychologization of the characters of the story "For the hearth" is an artistic "stage of the movement towards modernism" [22].

V. Vynnychenko continued implementing the "life is a fair" model in Ukrainian literature of the end of the nineteenth century. In the story "Lantsiuh" (Chain), relatives try to sell the main character, pretty Elena, as a commodity at a bargain price to a rich groom. However, an unexpected disease of smallpox changed her face, spoiled the "commercial" appearance, and the girl was no longer needed. The protagonist of the play "Bazaar" distorts her face, thus protesting against the perception of a person behind the outer shell, but, unfortunately, this also leads to her death. On the contrary, the hero of the story "Kuplia" (Purchase) tries to buy the love of a woman who prefers only 
heroes and daredevils. However, his "heroic" act is more like a crime - he burns his parents' estate, covering it with ideological beliefs. V. Vynnychenko, as a reasonably large number of artists of that time, artistically embodied the sharp social changes that intensified at the end of the century: the dominance of material values over spiritual ones.

A significant number of writers of the analyzed period, the artistic model of "life is a fair" has a typological component. This main character is permanently in a state of finding different ways to improve their financial situation. They do not stop at anything, gradually turning into predators who can trade their bodies for financial gain (Panas Myrnyi, T. Dreiser); to earn by immoral acts (I. Franko, O. Wilde, Guy de Maupassant), etc. To achieve their goal, they can sell the body and the soul, thus betraying themselves. However, such betrayal turns against the main characters. It leads to their death by suicide ("Picture of Dorian Gray" by O. Wilde, "For The Home Sake" (Dlia Domashnoho Ohnyshcha) by I. Franko), execution ("An American Tragedy" by T. Dreiser), infection with a deadly disease ("Poviia" (Prostitute) by Panas Myrnyi). Only immoral types who can sell even their souls for material goods could survive in a kind of duel with a predatory society.

The anthropological projection of the "life is a fair" model inspires the behavior of characters who are ready to do anything for the sake of a profitable sale of themselves at the highest price. The integration of this model into the late nineteenth and early twentieth centuries' artistic modernist discourse determines the artistic structure of Oscar Wilde's novel "The Picture of Dorian Gray" (1890). The writer is even compared to F. Nietzsche (an article by Kate Hex), calling both "rebels in the name of Beauty." In the novel, O. Wilde demonstrates resistance to Victorian dogmatism and his time trends and forces the addressee to empathize and create an aesthetic whole through the narrator, the Other's category, because the story is told in the third person. O. Wilde's narrative strategy is defined by outrage, the intention to surprise, shock, and, in the end, to make him think and appeal to his statements this reveals the dualism of the writer's work. On the one hand, he urges not to try to argue or prove something and takes back the human author's personal preferences, and on the other hand, as if involuntarily builds the plot and plot to provoke a reaction from the reader. $\mathrm{R}$. Bart notes that the impersonal mode is a traditional narrative mode. Still, their personal and non-personal alternation during the story is allowed. O. Wilde endows his heroes with reflections on the paradoxical and absurdity of absolute values, the fluidity of our lives, the need to pay the price for everything. Lord Henry, considered by researchers to be the author's alter ego, makes the following statement: “...we all take such pains to over-educate ourselves. In the wild struggle of existence, we want to have something that endures, and so we fill our minds with rubbish and facts in the silly hope of keeping our place. The thoroughly well-informed man - that is the modern ideal" [23]. The author of the novel is the bearer of omniscient and impersonal consciousness. He does not take part in the events he tells about, and there are no large-scale descriptions of paintings of nature, interiors, etc., but the novel is more focused on aesthetic and psychological perception. Such a narrator is intrinsic to the characters because he knows everything about their inner world. Still, he does not associate himself with any of them, remaining outside the course of events.

As we can see, the process of internal transformation of the character, its evolution or degradation, is vital for disclosing the artistic and interpretive model of the work.

\section{CONCLUSIONS}

Thus, the model of "life is a fair" incorporated the artistic search of writers, like one way to embody the imperfections of reality, which became a panoramic universe of human degradation, a literary projection of the process of transforming man into a commodity. Typological convergences are observed in the second half of the nineteenth century in the works of artists from different countries: English (W. Thackeray, T. Dreiser, etc.), in French literature (Guy de Maupassant, R. Roland, etc.), in Ukrainian (V. Vynnychenko, V. Pidmohylnyi), and others. The artists deepened and continued the traditions from the previous epochs. Emphasis on the emblems of the Baroque, romantic, realistic, modern paradigms of art made it possible to identify various aspects of the artistic model of "life is a fair."

Realistic novels of English literature and Ukrainian have the aim to harmonize the spiritual life of society. In their works, the merit of the English realists is that they appealed to modernity, depicted the social contradictions of the era, focusing on moral issues, family relationships, and human life values in general.

Considering the plot-thematic features of the mentioned prose works to be logical connected with W. Thackeray and I. Franko were the first representatives in the national literature. They realized the truth, which not all artists understand today. They saw the connection between social causes and spiritual consequences in the process of shaping human nature 
and understood this comprehensively, without simplifications and excessive straightforwardness.

Unlike the Ukrainian realists, who in their prose focused on the synthesis of realism and naturalism, the representatives of the realistic English novel actively used the ideas of artists of previous eras, focusing on philosophical subtext, likening the work to the natural flow of human existence. "Life is a fair" is a kind of decoding process through which the individual reader has the opportunity to interpret the text of the work, deepens the understanding of the characters. Early modernist stylistic versions of the artistic model of "life is a fair" in Ukrainian literature are initially influenced by positivist philosophy. However, mature modernism in the literature of pan-European scale offers the plot motif "everything for sale" in the aesthetic and existential planes. The texts are characterized by incomplete image, associativemetaphorical imagery.

Promising, in our opinion, is the expansion of temporal and genre boundaries of the model, i.e., further in-depth analysis of dramatic and lyrical works (for example, "Bazaar" by V. Vynnychenko, "Fair" by I. Lypa, "Bazaar" by E. Andievskaya, etc.).

Others include postmodern rhizomatic modifications of this multilevel artistic model in contemporary literature, including Malcolm Stanley Bradbury's "Doctor Criminale", "The World as a Supermarket", and "Map and Territory" by Michel Welbeck. The authors consider valuable the expansion of synchrony and diachrony of the study by analyzing the features of the representation of the model of "life is a fair" in postmodern and metamodern literature

\section{REFERENCES}

[1] A.F. Nekrylova, Russkye narodnye gorodskye prazdnyky, uveselenyya y zrelyshha. Konecz XVIII-nachalo XX veka, Yskusstvo, 1988.

[2] N. Yzhykova, Yarmarka v socyalno эkonomycheskom y kulturologycheskom aspektah, dys. ... kand. kulturologyy: 24.00.01 teoryya kultury, 24.00.02 - ystorycheskaya kulturologyya, Moscow, 1998.

[3] A.M. Golicyn, Vystavkovo-yarmarkova diyalnist pidpryyemstva, dys. kand. ekon. nauk: 08.06.01, Kyyivskyj nacionalnyj ekonomichnyj un-t im. Vadyma Getmana, Kyiv, 2006, 223 p.

[4] V. Yurchenko, Yarmarok v systemi tradycijnoyi kultury ukrayinciv (druga polovyna 19 - pochatok 20 st.), dys. kand. istorychnyh nauk: 07.00.05 - etnologiya, Kyiv, 2009, 239 p.

[5] T. Ryazanceva, Odisseya duxu: Kharakterni rysy doby baroko, Zarubizhna literatura 5 (1996) 7-8.

[6] O. Novyk, Tradycijnist motyvu yarmarku v tvorax ukrayinskykh romantykiv, in: Aktualni problemy filologiyi: movoznavstvo, literaturoznavstvo, metodyka vykladannya filologichnyh dyscyplin: zb. st. I Mizhnar. nauk.prakt. konf. (Mariupol, 23 kvitnya 2010 r.), Mariupol, 2010, pp. 82-86.

[7] Ukrayinska literatura XVII st.: Synkret. Pysemnist. Poeziya. Dramaturgiya. Beletrystyka, Naukova dumka, 1987, 608 p.

[8] A.K. Pavelieva, Khronotop yarmarky v povesty M. V. Hoholya "Sorochynskaya yarmarka": rol y funktsii, Problemy suchasnoyi filologiyi: lingvistyka, literaturoznavstvo, lingvodydaktyka 5 (2012) 116-120

[9] G.V. Samojlenko, Myr yarmarky u Hoholya y yoho predshestvennykov. Tvorcha spadshhyna M. Hoholya na peretyni epoch, Vydavnycztvo NDU im. M. Hoholya, Nizhyn, 2009, 210 p.

[10] T.V. Sharbenko, Transformacyya koncepta "yarmarka" v "stolychnykh" povestyah N. Gogolya y M. Bulgakova ("Nevskyj prospect" y "Sobache serdce"), in: N. V. Gogol y narodnaya kultura. Sedmye Gogolevskye chtenyya, CheRo, 2008, pp. 281-290.

[11] S. Bybyk, Koncept "yarmarok" v ukrayinskij smixovij kulturi, Kultura slova 91 (2019) 87-103.

[12] S.V. Lenska, Recepciya hoholivskykh motyviv u "Myrgorodskomu yarmarku" Oleny Zvychajnoyi, Filologichni nauky 30 (2019) 2025.

[13] N.F. Khairulina, Khudozhnya model "zhyttyayarmarok" $v$ ukrayinskij ta anglijskij literaturax: poetyka j semiotyka,. dys ... kand. filol. nauk: 10.01.05, Berdyansk, 2020.

[14] Akademichnyj tlumachnyj slovnyk ukrayinskoyi movy v 11 tomakh, Naukova dumka, Kyiv, 19701980.

[15] I. Devdiuk, Urban Existence in the Interwar English Literature, Respectus Philologicus 36(41) (2019) 73-83 DOI: http://dx.doi.org/10.15388/RESPECTUS.2019.3 6.41 .24 
[16] O.M. Bashkyrova, Genderni khudozhni modeli suchasnoyi ukrayinskoyi romanistyky, dys. .... doktora filol. nauk: 10.01.01 - ukrayins'ka literatura; 10.01.06 - teoriya literatury, Kyyivskyj universytet imeni Bory'sa Grinchenka, 2019, 464 p.

[17] P. Myrnyi, Tvory v triokh tomah, Dnipro, Kyiv. 1976.

[18] Characterization in "Vanity Fair", 2011, http://academic.brooklyn.cuny.edu/english/mela ni/novel_19c/thackeray/character.html

[19] M.P. Tkachuk, Istoriya ukrayinskoyi literatury XIX stolittya, Kyiv, 2002, 376 p.

[20] D.V. Zatonskyj, Yskusstvo romana y XX vek, Moskva, 1973, $215 \mathrm{p}$.

[21] D.S. Nalyvajko, Teoriya literatury j komparatyvistyka, Kyyevo-Mogylyanska akademiya, Kyiv, 2006, 347 p.

[22] I. Denysyuk, Rozvytok ukrayinskoyi maloyi prozy XIX - pochatku XX stolittya, Akademichnyj Ekspres, Lviv, 1999, 280 p.

[23] O. Wilde, The Picture of Dorian Gray. Selections, Progress, Moscow, 1979, 391 p.

[24] E. Brazgovskaya, Man in the 'Points of Intensity': Garden as a Space of SelfIdentification, Respectus Philologicus 26(31) (2014) 57-67. DOI: 10.15388/RESPECTUS.2014.26.31.4. 